\title{
Pengklasteran Kabupaten/Kota di Jawa Tengah berdasarkan Tenaga Kesehatan dengan Menggunakan Metode Ward dan K-Means
}

\author{
Sri Puji Lestari, Epha Diana Supandi, dan Pipit Pratiwi Rahayu \\ Program Studi Matematika Fakultas Sains dan Teknologi, UIN Sunan Kalijaga, JI. Marsda Adisucipto \\ No. 1 Yogyakarta, Indonesia
}

Korespondensi; Sri Puji Lestari, Email: sripujilestari511@gmail.com; Epha Diana Supandi, Email: epha.supandi@uin-suka.ac.id; Pipit Pratiwi Rahayu,Email: pipitrahayu@yahoo.com

\begin{abstract}
Abstrak
Analisis klaster merupakan suatu metode yang digunakan untuk mengelompokkan objek (kasus) ke dalam klaster (kelompok) yang relatif sama. Tujuan penelitian ini untuk mengklasterkan Kabupaten/Kota di Provinsi Jawa Tengah berdasarkan tenaga kesehatan tahun 2015 seperti tenaga medis, tenaga keperawatan, tenaga kebidanan, tenaga kefarmasian dan tenaga kesehatan lainnya dengan menggunakan metode Ward dan $\mathbf{K}$-Means. Hasil penelitian menunjukkan ada tiga klaster terbentuk dimana metode Ward menghasilkan nilai rasio simpangan baku sebesar 0,3019\% lebih besar jika dibandingkan dengan nilai rasio simpangan baku pada metode $K$-Means yaitu $0,2974 \%$. Pada kasus ini, metode $K$-Means merupakan metode yang lebih baik dibandingkan metode Ward.
\end{abstract}

Kata Kunci: Analisis klaster; metode K-Means; metode Ward; tenaga kesehatan

\begin{abstract}
Cluster analysis is a method used to group objects (cases) into clusters (groups) that are relatively the same. The purpose of this study is to classify districts/cities in Central Java Province based on health worker in 2015 such as medical personnel, nursing staff, midwifery staff, pharmacy personnel and health workers using the Ward and KMeans methods. The results show that there are three clusters formed where the Ward method produce a standard deviation ratio of $0.3019 \%$ greater than the standard deviation ratio in the K-Means method, which is $0.2974 \%$. In this case, the K-Means method is a better method than the Ward method
\end{abstract}

Keywords: Cluster Analysis; K-Means Method; Ward Method; health worker

\section{Pendahuluan}

Analisis klaster merupakan suatu metode, yang dipergunakan untuk mengklasifikasi atau mengelompokkan objek (kasus) seperti orang, produk (barang), toko, perusahaan ke dalam klaster (kelompok). (Supranto, 2010).

Penerapan analisis klaster dapat ditemui dalam berbagai bidang antara lain bidang pemasaran contohnya pembentukan segmen berdasarkan data demografi, psychographic profiles mengenali test market cities, bidang asuransi contohnya mengelompokkan responden berdasarkan alasan dalam memutuskan untuk membeli suatu produk asuransi. Bidang pendidikan contohnya dalam mengelompokkan mahasiswa pemohon beasiswa, bidang kependudukan contohnya pengelompokkan desa tertinggal di suatu Kabupaten/Kota. Bidang pangan contohnya mengelompokkan potensi produksi buah-buahan di suatu Provinsi. Penerapan analisis klaster dapat dilihat Sitepu dkk (2011), Aftina dkk (2012) serta Yim dan Ramdeen (2015).

Penerapan analisis klaster pada bidang kesehatan diantaranya mengelompokkan suatu wilayah berdasarkan tingkat kesehatan. Tenaga kesehatan menurut Undang-Undang adalah setiap orang yang mengabdikan diri dalam bidang kesehatan serta memiliki pengetahuan dan/atau keterampilan melalui pendidikan di bidang kesehatan yang untuk jenis tertentu memerlukan kewenangan untuk melakukan 
upaya kesehatan. Peran penting tenaga kesehatan itu sendiri dalam Undang-Undang Republik Indonesia nomor 36 tahun 2014 adalah untuk meningkatkan kualitas pelayanan kesehatan yang maksimal kepada masyarakat.

Tingkat penyebaran tenaga kesehatan di Indonesia belum merata ke seluruh wilayah terutama di Provinsi Jawa Tengah. Oleh karena itu, tujuan penelitian ini ingin mengelompokkan (mengklasterkan) Kabupaten/Kota di Jawa Tengah berdasarkan tenaga kesehatan seperti tenaga medis, tenaga keperawatan, tenaga kebidanan, tenaga kefarmasian dan tenaga kesehatan lainnya pada tahun 2015.

\section{Landasan Teori}

\section{Analisis Klaster}

Analisis klaster adalah teknik statistika yang digunakan untuk mengidentifikasi objek dengan memperhatikan beberapa kriteria. Analisis klaster termasuk analisis multivariat yang mewakili seluruh hubungan interdependensi, tidak ada pembedaan variabel bebas dan tak bebas dalam analisis ini (Supranto, 2010).

Prosedur pengklasteran dapat dilakukan dengan dua metode yaitu metode hirarki dan metode nonhirarki. Metode hirarki adalah teknik klastering yang membentuk tingkatan tertentu seperti struktur pohon dengan proses pengelompokkannya dilakukan secara bertingkat atau bertahap (Rafsanjadi dkk, 2012). Salah satu metode didalam kelas hirarki adalah metode Ward.

\section{Metode Ward}

Metode Ward (Wards method) adalah salah satu metode klaster dimana metode ini menggunakan error sum of square (ESS) sebagai pertimbangan dalam menggabungkan objek ke dalam klaster sehingga variansi di dalam klaster sekecil mungkin (Gudono, 2014).

Dimana rumus ESS adalah:

$$
E S S=\left(\sum_{i=1}^{n} x_{i y}^{2}-\left(\sum_{i=1}^{n} \bar{x}_{i y}\right)^{2}\right)
$$

Dimana,

$x_{i y}$ : Nilai untuk objek ke-i pada klaster ke-y

$n$ : Banyaknya objek dalam klaster yang terbentuk.

Misalkan diketahui sekumpulan data $x_{1}, x_{2}, \cdots, x_{N}$ dimana $x \in \mathfrak{R}^{p}$ maka langkah-langkah dalam metode Ward adalah (Johnson dan Wichern, 2001)

1. Setiap objek/pengamatan dianggap sebagai klaster, maka pada tahap ini mempunyai $N$ klaster dengan ESS bernilai nol.

2. Selanjutnya terbentuk klaster dengan memilih dua dari $N$ klaster yang memiliki nilai ESS terkecil. Secara sistematik, dari $N$ klaster akan berkurang 1 pada setiap tahap $(N-1)$.

3. Membuat kombinasi dua pasang klaster baru yang terdiri dari satu klaster yang telah terbentuk dan klaster yang lain, kemudian menghitung kembali ESS dari setiap pasang klaster baru dan memilih dua pasang klaster yang memiliki nilai ESS terkecil untuk digabungkan menjadi satu klaster.

4. Mengulangi langkah ke-3 sampai semua objek bergabung menjadi satu klaster.

\section{Metode K-Means}

Menurut Johnson dan Wichern (2001) teknik pengelompokkan non-hirarki di rancang untuk mengelompokkan objek penelitian menjadi $K$ klaster. Jumlah $K$ klaster harus ditentukan terlebih dahulu oleh peneliti. Metode non-hirarki ini menandai setiap objek masuk ke dalam klaster yang mempunyai pusat klaster (rata-rata) terdekat. Metode non-hirarki sering disebut sebagai metode $K$-Means. Pada dasarnya metodi $K$-Means berusaha untuk meminimalkan variasi dalam satu klaster dan memaksimalkan variasi antar klaster.

Secara umum analisis klaster metode $K$-Means menggunakan algoritma sebagai berikut:

1. Tentukan $K$ sebagai jumlah klaster yang dibentuk.

2. Menentukan centroid (titik pusat klaster) 
Penentuan centroid awal dilakukan secara random/acak dari objek-objek yang tersedia sebanyak $K$ klaster, kemudian menghitung centroid klaster ke-i berikutnya, dengan rumus sebagai berikut:

$$
C_{y k}=\frac{\sum_{k=1}^{p} x_{k}}{n}
$$

Dimana:

$C_{y k}$ : Nilai centroid dari klaster ke-y pada variabel ke- $k$

$x_{k} \quad$ : Nilai data pada variabel ke- $k$

$n \quad$ : Banyaknya objek dalam klaster yang terbentuk.

$p \quad$ : Banyaknya variabel yang diukur

3. Hitung jarak setiap objek ke masing-masing centroid dari masing-masing klaster. Untuk menghitung jarak antar objek dengan centroid menggunakan jarak Squared Euclidian:

$$
d_{(i y)}=\sum_{k=1}^{p}\left(x_{i k}-C_{y k}\right)^{2}
$$

Dimana:

$d_{(i y)}$ : Jarak Squared Euclidean antar objek ke-i dengan centroid klaster ke-y

$p \quad$ : Jumlah variabel klaster

$x_{i k} \quad$ : Nilai atau data dari objek ke- $i$ pada variabel ke- $k$

$C_{y k}$ : Nilai dari centroid klaster ke-y pada variabel ke-k.

4. Alokasikan masing-masing objek kedalam centroid yang paling dekat.

5. Lakukan iterasi kemudian tentukan posisi centroid baru dengan menggunakan persamaan (2).

6. Ulangi langkah ke-3 sampai posisi centroid baru yang terbentuk nilainya sama (tidak berubah).

\section{Bahan dan Metode}

Objek-objek yang digunakan dalam penelitian ini adalah:
1. Kab. Cilacap
14. Kab. Sragen
15. Kab. Grobogan
27. Kab. Pemalang
2. Kab. Banyumas
16. Kab. Blora
28. Kab. Tegal
3. Kab. Purbalinga
17. Kab. Rembang
18. Kab. Pati
19. Kab. Kudus
29. Kab. Brebes
4. Kab. Banjarnegara
30. Kota Magelang
5. Kab. Kebumen
20. Kab. Jepara
31. Kota Surakarta
6. Kab. Purworejo
21. Kab. Demak
32. Kota Salatiga
7. Kab. Wonosobo
33. Kota Semarang
8. Kab. Magelang
22. Kab. Semarang
10. Kab. Klaten
11. Kab. Sukoharjo
24. Kab. Kendal
12. Kab. Wonogiri
25. Kab. Batang
13. Kab. Karanganyar
26. Kab. Pekalongan
34. Kota Pekalongan
35. Kota Tegal

Pada penelitian ini terdapat 5 tenaga kesehatan yang akan digunakan sebagai variabel dalam mengklasterkan Kabupaten/Kota di Jawa tengah tahun 2015 yaitu:

$X_{1}$ : Tenaga medis (Medical personnel)

$X_{2}$ : Tenaga keperawatan (Nursing personned)

$X_{3}$ : Tenaga kebidanan (Midwifery personnel)

$X_{4}$ : Tenaga kefarmasian (Pharmacy Personned)

$X_{5}$ : Tenaga kesehatan lainnya (Other Health)

\section{Hasil dan Pembahasan}

Deskripsi jumlah tenaga kesehatan di Kabupaten/Kota Provinsi Jawa Tengah tahun 2015 untuk masingmasing variabel dapat dilihat pada gambar 1 dan 2 dibawah ini: 

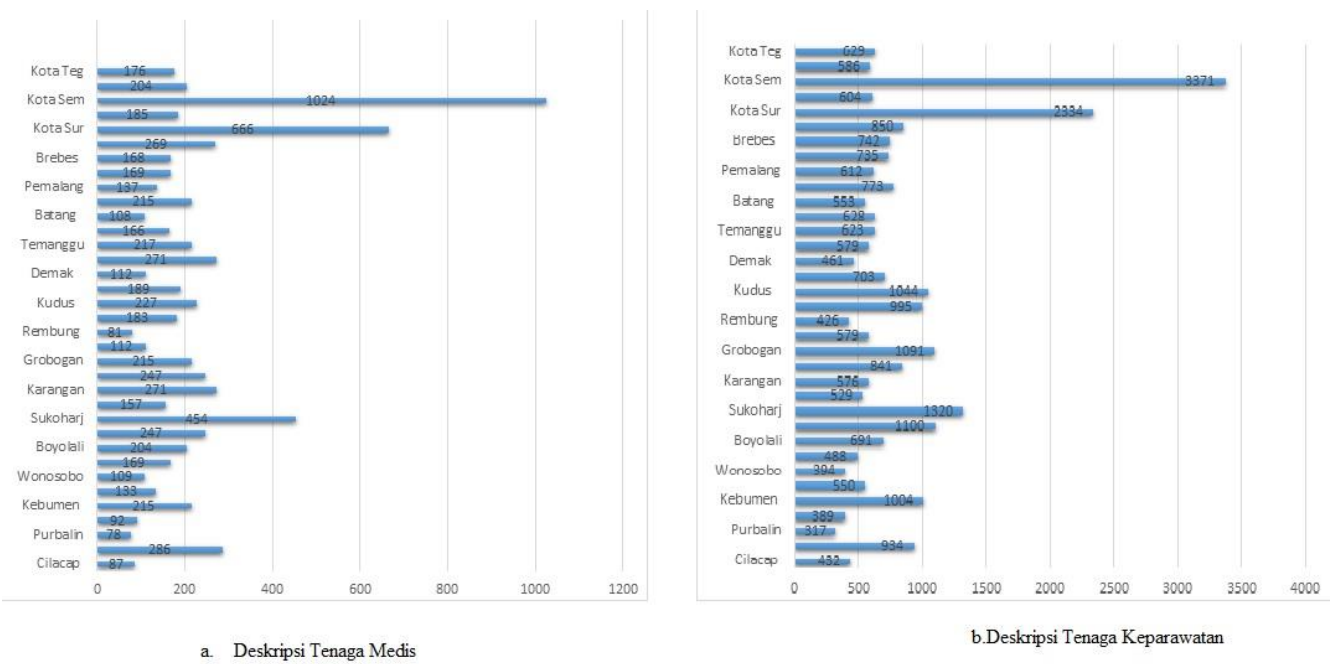

Gambar 1. Histogram Variabel Tenaga Medis dan Tenaga Keperawaran

Terlihat dalam gambar 1 pada panel a) dan b), jumlah tenaga medis dan tenaga keperawatan di kabupaten Semarang dan Surbaya memiliki nilai paling besar dibandingkan dengan kabupaten/kota lainnya.
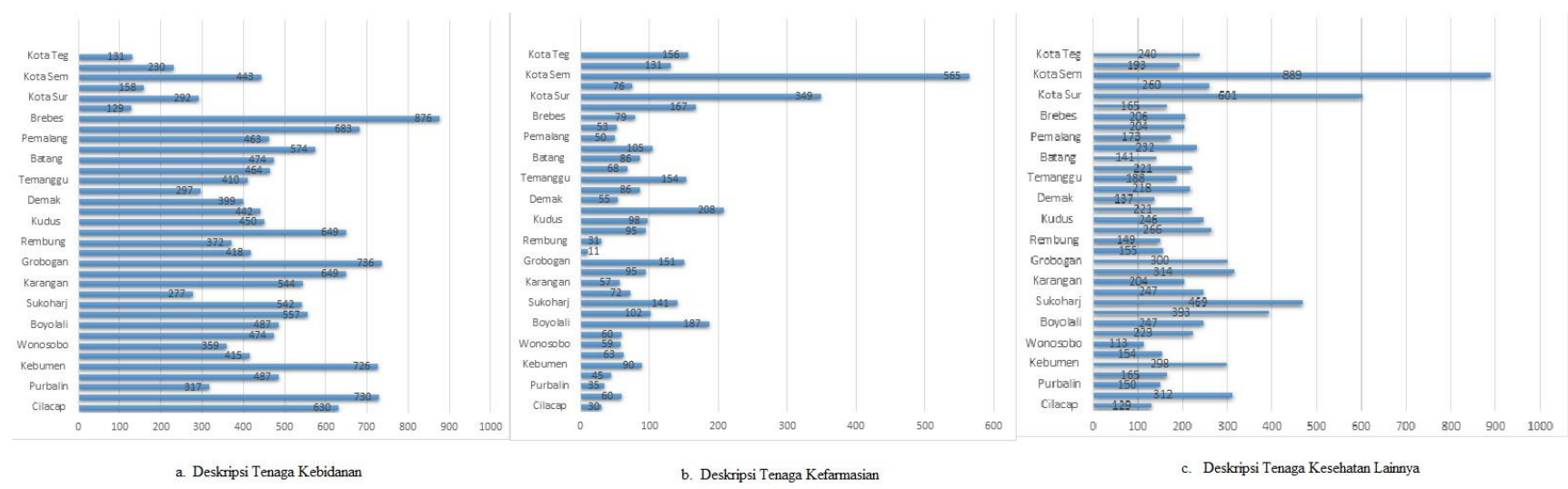

Gambar 2. Histogram Variabel Tenaga Kesehatan, Tenaga Kefarmasian dan Tenaga Kesehatan Lainya

Berdasarkan gambar 2 dapat dilihat bahwa jumlah tenaga kebidanan tertinggi terdapat pada Kabupaten Brebes, jumlah terbanyak untuk tenaga kefarmasian dan kesehatannya lainnya berada pada Kota Semarang yang juga merupakan ibukota provinsi Jawa Tengah.

Hasil klaster dengan menggunakan metode Ward terbentuk tiga klaser sebagai berikut:

1. Klaster pertama: terdiri dari 2 Kabupaten/Kota dimana pada klaster ini memiliki rata-rata tenaga kesehatan yang paling tinggi. Adapun anggota klaster pertama adalah:

Tabel 1. Klaster pertama dengan Mengunakan Metode Ward.

\begin{tabular}{lr}
\hline Kabupaten/Kota & Rata-rata Variabel \\
\hline 1. Kota Surakarta & 848,4 \\
2. Kota Semarang & 1258,4 \\
\hline Rata-rata & 1053,4 \\
\hline
\end{tabular}

2. Klaster kedua: beranggotakan $11 \mathrm{Kabupaten/Kota} \mathrm{dimana} \mathrm{klaster} \mathrm{kedua} \mathrm{ini} \mathrm{memiliki} \mathrm{rata-rata} \mathrm{tenaga}$ kesehatan lebih rendah daripada klaster satu. Adapun anggota klaster kedua adalah: 
Tabel 2. Klaster kedua dengan mengunakan Metode Ward.

\begin{tabular}{lr}
\hline Kabupaten/Kota & Rata-rata Variabel \\
\hline 1. Banyumas & 464,4 \\
2. Kebumen & 466,6 \\
3. Klaten & 479,8 \\
4. Sukoharjo & 585,2 \\
5. Sragen & 429,2 \\
6. Grobogan & 498,6 \\
7. Pati & 437,6 \\
8. Kudus & 413 \\
9. Pekalongan & 379,8 \\
10. Tegal & 368,8 \\
11. Brebes & 414,2 \\
\hline Rata-rata & 448,8363 \\
\hline
\end{tabular}

3. Klaster tiga: klaster yang beranggotakan 22 Kabupaten/Kota dimana klaster ini memiliki rata-rata tenaga kesehatan paling rendah dibanding rata-rata variabel pada klaster pertama dan kedua. Anggota klaster ketiga adalah:

Tabel 3. Klaster ketiga dengan mengunakan Metode Ward.

\begin{tabular}{lrlr}
\hline Kabupaten/Kota & Rata-rata Variabel & Kabupaten/Kota & Rata-rata \\
\hline 1. Cilacap & 261,6 & 2. Jepara & 352,6 \\
3. Purbalinga & 179,4 & 4. Demak & 232,8 \\
5. Banjarnegara & 235,6 & 6. Semarang & 290,2 \\
7. Purworejo & 263 & 8. Temanggung & 318,4 \\
9. Wonosobo & 206,8 & 10. Kendal & 309,4 \\
11. Magelang & 282,8 & 12. Batang & 272,4 \\
13. Boyolali & 363,2 & 14.Pemalang & 287 \\
15. Wonogiri & 256,4 & 16. Kota Magelang & 316 \\
17. Karanganyar & 330,4 & 18. Kota Salatiga & 256,6 \\
19. Blora & 255 & 20.Kota Pekalongan & 268,8 \\
21. Rembung & 211,8 & 22. Kota Tegal \\
\hline Rata-rata & \multicolumn{2}{c}{$\mathbf{2 7 3 , 4 8}$} \\
\hline
\end{tabular}

Hasil pengklasteran dengan metode Ward dapat digambarkan pada gambar 4 berikut ini:

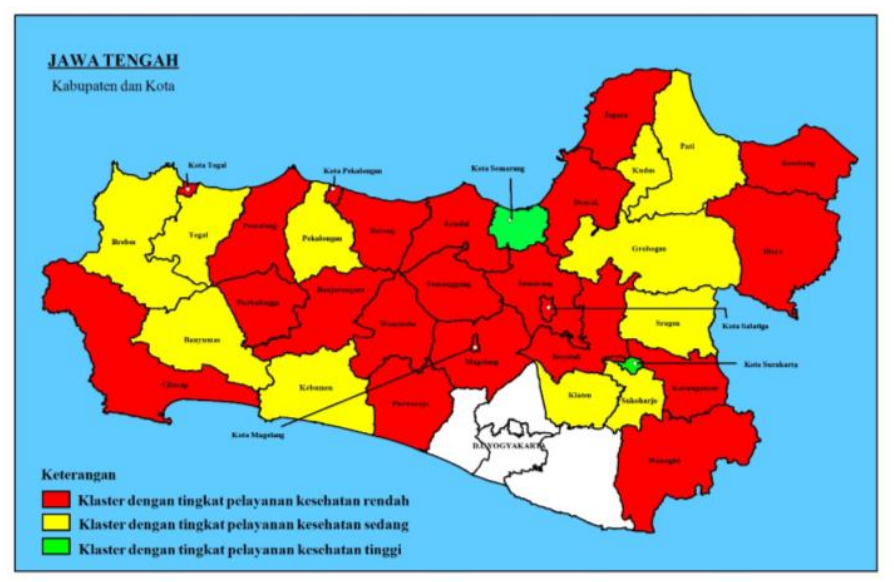

Gambar 4. Hasil pengklasteran dengan menggunakan Metode Ward. 
Gambar 4 memperlihatkan kelompok Kabupaten/Kota dengan tingkat kualitas kesehatan yang tinggi hingga rendah berturut-turut adalah klaster 1, klaster 2, dan klaster 3, yang digambarkan pada peta Provinsi Jawa Tengah.

Hasil pengklasteran dengan menggunakan metode $K$-Means menghasilkan tiga klaster dengan ratarata tiap variabel sebagai berikut:

Tabel 4. Rata-rata variabel pada tiap klaster dengan metode K-Means.

\begin{tabular}{lrrr}
\hline Variabel & Klaster 1 & Klaster 2 & Klaster 3 \\
\hline Tenaga Medis & 186 & 666 & 1024 \\
Tenaga Keperawatan & 690 & 2334 & 3371 \\
Tenaga Kebidanan & 471 & 292 & 443 \\
Tenaga Kefarmasian & 90 & 349 & 565 \\
Tenaga Kesehatan Lainnya & 222 & 601 & 889 \\
\hline
\end{tabular}

Hasil pengklasteran dapat digambarkan pada peta Provinsi Jawa Tengah berikut ini:

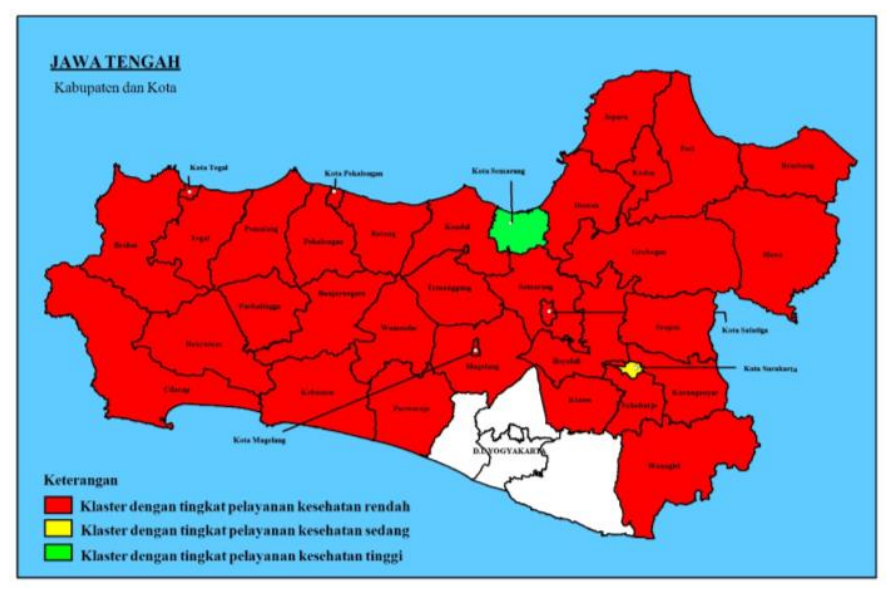

Gambar 5. Hasil pengklasteran dengan menggunakan Metode K-Means.

Berdasarkan gambar 5 dapat dilihat bahwa klaster pertama beranggotakan 33 Kabupaten/Kota, klaster dua beranggotakan 1 Kabupaten/Kota dan klaster tiga beranggotakan 1 Kabupaten/Kota. Anggota masing masing klaster adalah:

1. Klaster satu mempunyai anggota Cilacap, Banyumas, Purbalinga, Banjarnegara, Kebumen, Purworejo,

Wonosobo, Magelang, Boyolali, Klaten, Sukoharjo, Wonogiri, Karanganyar, Sragen, Grobogan, Blora,

Rembung, Pati, Kudus, Jepara, Demak, Semarang, Temanggung, Kendal, Batang, Pekalongan,

Pemalang, Tegal, Brebes, Kota Magelang, Kota Salatiga, Kota Pekalongan, Kota Tegal.

2. Klaster dua beranggotakan Kota Surakarta.

3. Klaster tiga beranggotakan Kota Semarang.

Hasil pengklasteran dengan menggunakan metode Ward dan K-Means sama sama menghasilkan tiga klaster yaitu klaster yang mempunyai tingkat pelayanan tenaga kesehatan yang sangat baik (tinggi), sedang dan rendah.

Selanjutnya, untuk mengetahui kinerja kedua metode pengklasteran tersebut digunakan kriteria dua simpangan baku yaitu: simpangan baku dalam klaster $\left(S_{w}\right)$ dan simpangan baku antar antar klaster $\left(S_{b}\right)$. Suatu metode terbaik apabila mempunyai nilai rasio antara $S_{w}$ dan $S_{b}$ paling kecil artinya klaster tersebut mempunyai homogenitas yang tinggi. 
Hasil perhitungan $S_{w}$ dan $S_{b}$ disajikan pada tabel berikut ini:

Tabel 5. Rasio antara Simpangan Baku Dalam dan Simpangan Baku Antar Klaster.

\begin{tabular}{lrr}
\hline Simpangan Baku & Metode Ward & Metode K-Means \\
\hline Simpangan baku dalam klaster $\left(S_{w}\right)$ & 156,0499 & 154,7042 \\
Simpangan baku antar klaster $\left(S_{b}\right)$ & 516,8633 & 520,0794 \\
\hline Rasio $\frac{S w}{S b}$ & $0,3019 \%$ & $0,2974 \%$ \\
\hline
\end{tabular}

Pada tabel 5 terlihat bahwa simpangan baku dalam klaster $\left(S_{w}\right)$ metode Ward lebih besar daripada metode $K$-Means. Sedangkan simpangan antar klaster $\left(S_{b}\right)$ metode Ward lebih kecil daripada metode K-Means. Oleh karena itu, pada kasus ini metode $K$-Means lebih baik dalam mengklasterkan Kabupaten/Kota di Provinsi Jawa Tengah berdasarkan variabel tenaga kesehatan dibandingkan metode Ward.

\section{Kesimpulan}

Hasil pengklasteran Kabupaten/Kota di Provinsi Jawa Tengah berdasarkan variabel tenaga kesehatan dengan menggunakan metode Ward dan K-Means menghasilkan tiga klaster. Pada kasus ini, pengklasteran dengan metode K-Means lebih baik dibandingkan metode Ward karena menghasilkan rasio antara $S_{w}$ dan $S_{b}$ paling kecil. Dengan kata lain, pengklasteran dengan metode K-Means menghasilkan tingkat homogenitas dalam klaster yang paling kecil (mirip) yang sesuai dengan tujuan analisis klaster.

\section{Referensi}

[1] Gudono. 2014. Analisis Data Multivariat. Yogyakarta: BPFE.

[2] J. Supranto. 2010. Analisis Multivariat Arti dan Interpretasi. Jakarta, Rineka Cipta.

[3] R.A. Johnson and D.W. Wichern. 2001. Applied Multivariate Statistical Analysis (5th Edition). New York, Prentice Hall.

[4] Rafsanjani, M Kuchaki., Varzaneh, Z Asghari., and Chukanlo, N Emami. (2012). A Survey of Hierarchical Clustering Algorithms. The Journal of Mathematics and Computer Science, 5(3), 229-240.

[5] Sitepu, Robinson., Irmeilyana., dan Gultom, Berry. (2011). Analisis Cluster terhadap Tingkat Pencemaran Udara pada Sektor Industri di Sumatera Selatan. Jurnal Penelitian Sains, 14, 14303 11-14303 17.

[6] T. Aftina, B. Santosa dan A.L Barakbah. (2012). Analisa Perbandingan Metode Hierarchical Clustering, K-means dan Gabungan Keduanya dalam Cluster Data (Studi Kasus: Problem Kerja Praktek Jurusan Teknik Industri ITS). Jurnal Teknik ITS. 1(1), A 521 A 525.

[7] Yim, Odilia., \& Ramdeen, Kylee T. (2015). Hierarchical Cluster Analysis: Comparison of Three Linkage Measures and Application to Psychological Data. The Quantitative Metods for Psychology, 11(1), 8-21. 
THIS PAGE INTENTIONALLY LEFT BLANK 